\title{
Pelatihan Pembuatan dan Pengembangan Instrumen (Non-Tes) Penelitian bagi Mahasiswa Pendidikan Bahasa Inggris Universitas Lancang Kuning
}

\author{
$\operatorname{Marwa}^{1} \&$ Herlinawati ${ }^{2}$ \\ ${ }^{1,2}$ Pendidikan Bahasa Inggris, FKIP, Universitas Lancang Kuning \\ ${ }^{1}$ marwaoke81@yahoo.com \\ linapazir@yahoo.com
}

\begin{abstract}
ABSTRAK
Penguasaan metodologi penelitian merupakan hal penting bagi mahasiswa dimana mereka dituntut untuk mampu melakukan penelitian sebagai bagian dari kegiatan akademik. Beragam metode penelitian mempunyai cara berbeda dalam teknik pengumpulan data. Salah satunya adalah metode survei yang banyak digunakan peneliti dimana angket atau kuesioner selalu dipakai sebagai teknik pengumpulan data. Namun, berdasarkan fakta yang ditemukan banyak mahasiswa peneliti yang belum memahami secara jelas bagaimana merancang, menggunakan, dan menganalisa angket dengan benar. Hal ini menjadi permasalahan mahasiswa prodi Pendidikan Bahasa Inggris Fakultas Keguruan dan Ilmu Pendidikan Universitas Lancang Kuning Pekanbaru bahwa mereka masih belum memahami secara jelas teknis pembuatan angket yang layak untuk dipakai sebagai instrumen pengumpulan data penelitian dan bagaimana mengolah data yang diperoleh dari angket. Oleh karena itu, tim pelaksana pengabdian merasa perlu untuk melaksanakan kegiatan pelatihan yang bertujuan untuk meningkatkan kemampuan serta memperkaya pengetahuan mahasiswa melalui pelatihan/workshop untuk mengatasi permasalahan ini. Kegiatan ini dilakukan selama 1 hari yang berlangsung selama 4,5 jam dan dibagi menjadi 2 sesi. Pada sesi pertama, mahasiswa diberikan topik dan materi pembuatan angket beserta contohnya. Selanjutnya, pada sesi kedua peserta diberikan penugasan membuat angket dibimbing langsung oleh tim pelaksana pengabdian. Penyelesaian tugas pelatihan dilanjutkan diluar sesi selama dua minggu dengan bimbingan online via grup WhatsApp. Dengan adanya kegiatan ini, dapat dilihat bahwa peserta pelatihan memahami langkah-langkah pembuatan instrumen angket dan dapat menyelesaikan tugas-tugas pelatihan yang diberikan kepada mereka. Mahasiswa mampu membuat angket penelitian sendiri dan dapat digunakan untuk kepentingan pengumpulan data untuk penyelesaian tugas akhir mereka.
\end{abstract}

Kata kunci: Pelatihan, pembuatan angket, FKIP, Prodi Bahasa Inggris

\section{ABSTRACT}

Research methodology is a pivotal thing to students-researchers since they are required to conduct a lot of scientific research in academic settings. Different research methods result to different ways of data collection techniques. In fact, survey design has been frequently used along with the questionnaire as the common instrument to collect data. However, many students-researchers have not fully understood how to construct/design, use and analyze a questionnaire well. This similar case happened to the English students in the Faculty of Education and Teachers Training in Universitas Lancang Kuning Pekanbaru. Therefore, the outreach program team from the faculty intended to solve the problem by conducting a workshop in order to upgrade the students-researchers' knowledge and understanding of how to construct and analyze a questionnaire. The workshop was done in one day within the duration of 4.5 hours with two sessions. In the first session, the presenters gave the students the workshop topic and materials in terms of how to design and analyze a questionnaire. In the second session, the students were guided to construct a questionnaire and it then was continued with two weeks' task completion. The presenters also facilitated the students with the online discussion via WhapsApp group. As a matter of fact, the students-researchers gradually understand and know how to construct a questionnaire. They could construct their own research instruments for the sake of their data collection to complete the thesis writing.

Keywords: Workshop, Questionnaire, Faculty of Education and Teachers Training, English Students 


\section{PENDAHULUAN}

Metode penelitian merupakan serangkaian upaya dan cara sistematis yang diterapkan oleh peneliti dalam rangka memperoleh jawaban atas apa yang menjadi pertanyaan penelitiannya. Metode penelitian secara langsung berkaitan dengan bagaimana mengetahui sesuatu. Peneliti membutuhkan metode penelitian ketika akan melakukan penelitian. Dalam kenyataannya bahwa tidak semua pengetahuan diperoleh melalui metode penelitian. Namun pengetahuan ilmiah tidak bisa diperoleh tanpa menggunakan metode penelitian. Beberapa jenis metode penelitian sering disebut metodologi, dan juga disebut teknik. Misalnya, metodologi penelitian survei, teknik observasi, dan sebagainya. Pendefinisian istilah metode penelitian, sekali lagi, hanya didasarkan pada cara memperoleh, mengolah dan analisis datanya. Salah satu metode penelitian yang paling sering digunakan adalah metode survei. Menurut Nazir (2005) penelitian survei adalah penyelidikan yang dilakukan untuk mendapatkan fakta-fakta dari gejala yang ada dan mencari keterangan-keterangan secara faktual baik tentang institusi sosial, ekonomi atau politik dari suatu kelompok atau suatu individu.

Metode survei menggunakan kuesioner atau angket sebagai instrumen penelitiannya untuk mengumpulkan data. Kuesioner tersebut ditujukan kepada sampel penelitian yang merupakan representasi populasi (Cresswell, 2012). Setelah dikumpulkan, data diolah secara manual atau menggunakan sofware pengolahan data. Pengolahan dimulai dengan proses koding. Setelah diolah, data dianalisis. Sama seperti pengolahan data, proses analisis bisa dilakukan secara manual atau dengan bantuan software komputer. Namun, sebelum melakukan penelitian dengan metode survei hingga sampai pada tahap pengolahan data baik secara manual maupun dengan bantuan software, hal yang sangat penting yang juga harus dikuasai oleh seorang peneliti adalah bagaimana cara membuat instrumen dalam metode survei ini.

Salah satu landasan utama yang harus diperhatikan sebagai bagian dari keseluruhan cara membuat angket adalah memahami pertanyaan penelitian atau rumusan masalah. Angket dibuat dengan tujuan mengumpulkan data yang nantinya akan diolah dalam rangka menjawab pertanyaan penelitian. Dalam dunia penelitian akademik, angket banyak digunakan sebagai instrumen pengumpulan data, khususnya bila data yang akan dikumpulkan berupa gagasan, pendapat, atau pengalaman pribadi sekelompok orang (Saleh, 2008). Hal yang juga sangat penting dalam penyusunan sebuah angket adalah instrumen ini harus memenuhi persyaratan yaitu mudah ditanyakan, mudah dijawab dan mudah diproses (Kasnodiharjo, 1993).

Sebagai bagian masyarakat akademik, mahasiswa sangat perlu untuk memiliki kemampuan membuat salah satu dari instrumen penelitian yaitu angket untuk kepentingan pengumpulan data penelitian dalam metode survei karena tidak jarang mereka merancang model penelitian ini dalam tugas-tugas akademik maupun dalam rangka penyelesaian tugas akhir (skripsi). Oleh karena itu, mereka perlu mengetahui beberapa prinsip dasar dalam pembuatan angket penelitian. Pengetahuan akan prinsip dasar pembuatan angket harus dikuasai untuk memudahkan peneliti dalam proses pembuatan kuesioner. Beberapa prinsip dasar berkaitan dengan: isi pertanyaan, cara pemakaian angket, dan jenis pertanyaan. Ketiganya perlu dipahami oleh peneliti terlebih dahulu sebelum menerapkan cara membuat angket penelitian. Isi pertanyaan angket dapat dikategorikan menjadi empat jenis yaitu pertanyaan angket tentang fakta sosial, pertanyaan angket tentang pendapat atau sikap informan terhadap sesuatu, pertanyaan angket tentang informasi, dan pertanyaan angket tentang persepsi diri (Saleh, 2008). Sebagai penjelasan tambahan, Gall (2003) menyatakan ada beberapa langkah penting dalam penyusunan angket yaitu menentukan tujuan penelitian, kelompok sampel, merancang kuesioner, anonomitas, bentuk item, mengukur sikap/perilaku, uji cobakan angket, komunikasi awal dengan sampel, surat pengantar angket, tindak lanjut dan menganalisis data angket.

Untuk memberikan pemahaman tentang pembuatan angket penelitian kepada mahasiswa pendidikan Bahasa Inggris Fakultas Keguruan dan Ilmu Pendidikan Universitas Lancang Kuning Pekanbaru, maka pihak kampus dalam hal ini tim pengabdian kepada masyarakat menaja kegiatan tambahan di luar pertemuan kelas dengan menghadirkan dosen peneliti yang biasa melakukan kegiatan pembuatan instrumen penelitian baik jenis test maupun non-test. Mengingat pentingnya 
kemampuan membuat instrumen angket bagi mahasiswa peneliti dimana seorang peneliti selayaknya mengetahui dan memahami segala elemen yang berhubungan dengan angket mulai dari isi pertanyaan, pemakaian dan jenis pertanyaan angket. Melalui kegiatan workshop pelatihan pembuatan instrumen ini diharapkan mahasiswa prodi pendidikan Bahasa Inggris FKIP Unilak dapat membuat intstrumen angket yang kemudian dapat mereka gunakan dalam pengumpulan data penelitian mereka. Melalui kegiatan pelatihan ini juga diharapkan mahasiswa juga mampu mengolah data penelitian yang didapat dari instrumen angket baik secara manual maupun dengan bantuan software statistik.

\section{METODE KEGIATAN}

Pelatihan pembuatan instrumen angket penelitian ini dilaksanakan pada bulan Juni 2019 di Fakultas Keguruan dan Ilmu Pendidikan Universitas Lancang Kuning yang terletak di jalan Yos Sudarso KM. 08, Rumbai, Pekanbaru-Riau. Kegiatan workshop ini dilaksanakan dalam 1 hari dilanjutkan dengan 2 minggu penugasan mandiri dan kelompok untuk menyelesaikan angket penelitian. Peserta yang terlibat dalam kegiatan ini adalah mahasiswa Program studi Pendidikan Bahasa Inggris Fakultas Keguruan dan Ilmu Pendidikan Universitas Lancang Kuning. Jumlah peserta yang mengikuti pelatihan sebanyak 50 orang mahasiswa semester VI dan VIII yang akan dan sedang mengerjakan tugas akhir mereka. Kegiatan ini diawali dengan metode observasi lapangan dan wawancara kepada dosen-dosen dan mahasiswa ketika mengidentifikasi masalah mitra, dan dilanjutkan dengan kegiatan workshop yang terdiri dari ceramah, diskusi (tanya jawab), dan pelatihan pembuatan instrument serta pendampingan.

\subsection{Observasi Lapangan dan Wawancara}

Melakukan tahap analisis situasi berupa observasi lapangan dan wawancara kepada dosen-dosen dan mahasiswa FKIP di kampus UNILAK tentang penguasaan mahasiswa tentang instrumen penelitian khususnya untuk metode survei. Hal ini bertujuan untuk mengidentifikasi permasalahan mitra pengabdian untuk dicarikan solusinya.

\subsection{Metode ceramah}

Metode ceramah diberikan untuk memberikan pemahaman kepada para peserta tentang topik dan materi pembuatan instrumen penelitian yaitu angket dan contoh-contohnya. Dalam ceramah diuraikan kerangka materi secara, jelas, mudah dipahami, dan aplikatif. Metode ceramah dalam pelatihan ini diusahakan untuk menghindari pembahasan teoritis yang berlarut-larut dan lebih menekankan pada contoh-contoh kasus beserta pemecahannya. Penyajian materi akan dilanjutkan dengan tanya jawab, diskusi, dan kegiatan pembuatan instrumen angket.

\subsection{Metode Diskusi (Tanya Jawab)}

Metode diskusi (tanya jawab) dipilih untuk lebih memberikan kesempatan kepada para peserta membahas, mempertanyakan, menggarisbawahi, memberi masukan, dan atau memperdalam materi pelatihan pembuatan instrumen angket yang diceramahkan. Metode ini diberi porsi waktu yang lebih banyak daripada ceramah.

\subsection{Pelatihan dan Pendampingan}

Pelatihan pembuatan angket dibimbing langsung oleh 2 pemateri (Dr. Marwa, M.A dan Dr. Herlinawati, M.Ed dengan memberikan beberapa topik angket sebagai bahan penugasan kepada peserta pelatihan yaitu teachers' perceptions using ict, language learning strategy (lls) on reading - literature circle strategies, students' perceptions on online learning, inventory: high ICT-oriented students, low ICT-oriented students, and conventional students, students' plagiarism awareness, students' intercultural awareness, dan students' tpd (teacher professional development) orientations. Penyelesaian tugas pelatihan dilanjutkan di luar sesi selama dua minggu dengan bimbingan online via grup WhatsApp.

\section{HASIL \& PEMBAHASAN}

Kegiatan workshop pelatihan pembuatan instrumen penelitian non-test yaitu angket melibatkan mitra mahasiswa pendidikan Bahasa Inggris yang tergabung dalam English Department Students Association (EDSA) Fakultas Keguruan dan Ilmu Pendidikan dilaksanakan dalam beberapa tahapan. Kegiatan pertama yaitu tim pelaksana melakukan tahap analisis situasi berupa observasi lapangan dan wawancara kepada dosen-dosen dan mahasiswa FKIP di kampus UNILAK tentang penguasaan mahasiswa dalam bidang instrumen penelitian khususnya untuk metode survei. Setelah itu tim pelaksana pengabdian mengidentifikasi permasalahan 
target pengabdian untuk dicarikan solusinya. Akhirnya tim pelaksana memutuskan untuk memberikan pelatihan workshop pembuatan angket kepada mahasiswa pendidikan Bahasa Inggris semester VI yang dikoordinir oleh EDSA FKIP UNILAK.

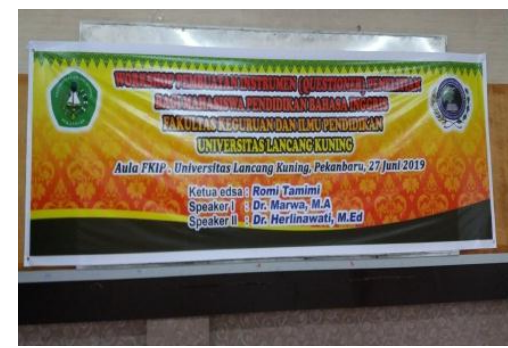

Gambar 1. Spanduk Workshop Pelatihan Pembuatan Instrumen Penelitian

Pada hari Jum'at (pukul 7.30-12.00), 27 Juni 2019, kegiatan workshop dilaksanakan dengan dihadiri oleh 50 orang mahasiswa. Sebelum pemberian materi dan pelatihan wokshop, pemateri pertama (Dr. Marwa, M.A) memberikan sebuah tes diagnostik yang terdiri dari 12 pertanyaan tentang instrumen angket kepada peserta workshop. Waktu yang diberikan untuk menjawab pertanyaan tes selama 15 menit. Adapun 12 pertanyaan yang harus dijawab oleh peserta yang telah dibagi dalam 7 grup adalah sebagai berikut:

1. Apa pengertian dan kegunaan angket?

2. Adakah kesamaan angket dengan tes?

3. Apa yang dimaksud dengan test dan non-test instrument?

4. Hal apa saja yang harus dipersiapkan untuk membuat sebuah angket?

5. Apa saja elemen penting pada sebuah angket?

6. Berapa jumlah pertanyaan/pernyataan minimal atau maksimal yang ada pada sebuah angket?

7. Apa yang dimaksud dengan construct validity?

8. Perlukah angket divalidasi (expert validation),

9. Apa yang dimaksud dengan "likert scale"?

10. Apa itu faktor analisis?

11. Apa itu "adopt" dan "adapt" pada sebuah angket?

12. Bagaimana mendistribusikan angket, menskor dan menganalisa angket?

Adapun tujuan pemberian tes diagnostik ini adalah untuk mengetahui sejauh mana pemahaman peserta pelatihan terhadap topik workshop (pembuatan angket penelitian) yang mereka ikuti. Hasil dari test ini dapat dilihat pada table 3.1 .
Tabel 3.1 Hasil Test Diagnostik Peserta Workshop Tentang Angket

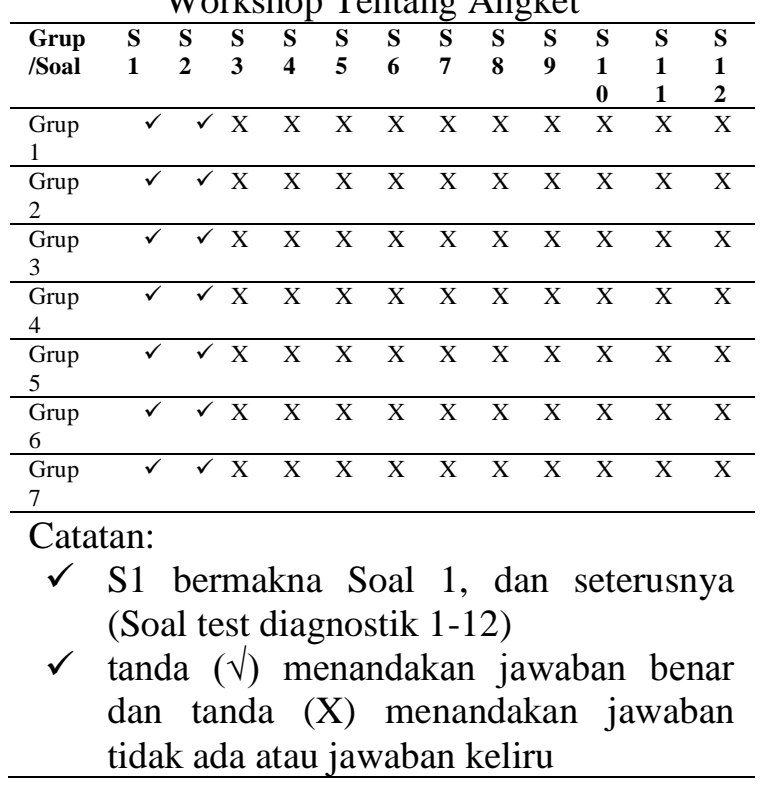

Dari table 3.1 dapat dilihat bahwa peserta yang tergabung dalam 7 grup hanya bisa menjawab pertanyaan tes diagnostik 1 dan 2 (Apa pengertian dan kegunaan angket? Dan Adakah kesamaan angket dengan tes?). Sementara pertanyaan 3-12 tidak bisa dijawab dengan benar oleh 7 grup peserta workshop. Tim pelaksana pengabdian menyimpulkan bahwa peserta pelatihan memiliki pengetahuan yang sangat minim tentang pembuatan instrumen angket penelitian. Dengan kata lain, mereka tidak mengetahui hal apa saja yang harus dipahami untuk bisa membuat angket penelitian yang benar.

Selanjutnya tim pelaksana pengabdian meneruskan kegiatan berikutnya yaitu penyampaian materi workshop mulai pukul 8.10-9.20 WIB. Pada sesi ini Dr. Herlinawati mempresentasikan materi (ppt) tentang pembuatan angket penelitian yang mencakup semua informasi dari 12 pertanyaan test diagnostik yang sudah diujikan sebelumnya. Tim pelaksana pengabdian juga memberikan handouts kepada peserta. Pemateri dengan metode ceramah memberikan pemahaman kepada para peserta tentang topik dan materi pembuatan instrumen penelitian yaitu angket dan contoh-contohnya. Dalam ceramah diuraikan kerangka materi secara, jelas, mudah dipahami, dan aplikatif. Metode ceramah dalam pelatihan menyeimbangkan antara aspek teoritis dan juga praktek untuk mengarahkan peserta workshop. Penyajian materi kemudian dilanjutkan dengan tanya jawab, diskusi, dan kegiatan pembuatan instrumen angket. 


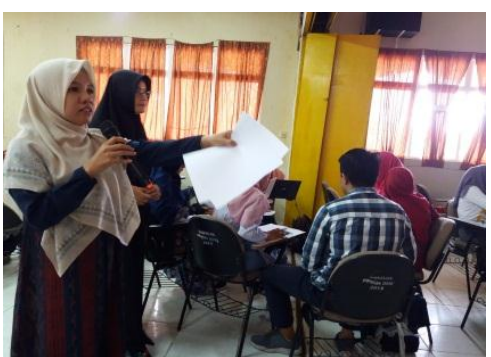

Gambar 2. Pelatihan Pembuatan Angket Penelitian

Pada pukul 9.45, peserta memulai kegiatan pembuatan angket dalam kerja kelompok (7 grup). Workshop pembuatan angket kemudian dibimbing langsung oleh 2 pemateri (Dr. Marwa, M.A dan Dr. Herlinawati, M.Ed dengan memberikan beberapa topik untuk mengembangkan angket sebagai bahan penugasan kepada peserta pelatihan. Topik-topik yang diberikan yaitu:

1. Teachers' Perceptions Using ICT

2. Language Learning Strategy (LLS) on reading: Literature Circle Strategies

3. Students' Perceptions on Online Learning

4. Inventory:High ICT-Oriented Students, Low ICT-Oriented Students, and Conventional Student

5. Students' Plagiarism Awareness

6. Students' Intercultural Awareness

7. Students' Tpd (Teacher Professional Development) Orientations

Adapun langkah-langkah pembuatan instrument angket penelitian yang dikerjakan oleh peserta workshop adalah 1) menelusuri teori-teori (minimal 5) yang berhubungan dengan topik angket/variabel yang sudah dibagi ke masing-masing grup menggunakan media handphone, 2) menyusun tabel kerja angket mulai kolom konsep teoritis, dimensi, variable \& sub-variabel, indikator dan item/pertanyaan, 3) mengisi kolom-kolom tabel kerja dengan teori-teori yang sesuai, 4) membuat 5-10 pertanyaan/pernyataan dari beberapa indikator yang sudah dibuat (meskipun belum selesai semua), 5) melaporkan hasil kerja kelompok secara lisan, dan 6) mengumpulkan kertas kerja kelompok. Kegiatan ini berlangsung hingga pukul 11.50. Untuk penyempurnaan tugas pembuatan angket hingga tuntas, tim pelaksana pengabdian memberikan waktu selama 1-3 minggu kepada masing-masing grup. Konsultasi tugas dapat dilakukan via grup WhatsApp.

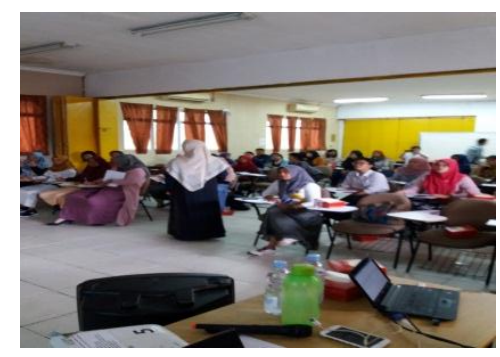

Gambar 3. Penyampaian Materi Pelatihan

Setelah mengevalusi kertas kerja langkah-langkah pembuatan angket yang dikumpulkan kepada pemateri, dapat disimpulkan bahwa peserta pelatihan sudah memahami materi yang diberikan dan mereka juga mampu membuat angket sesuai dengan topik yang sudah diberikan perkelompok. Keberhasilan peserta dalam membuat angket pada sesi kelas (hari Jum'at, 27 Juni 2019) dapat dilihat dari tabel 3.2 berikut.

Tabel 3.2 Hasil Evaluasi Kertas Kerja

Kelompok dalam Pembuatan Angket

Penelitian

\begin{tabular}{cccccc}
\hline $\begin{array}{c}\text { Grup/Ele } \\
\text { men } \\
\text { Angket }\end{array}$ & $\begin{array}{c}\text { Konse } \\
\text { Teorit } \\
\text { is }\end{array}$ & $\begin{array}{c}\text { Dimen } \\
\text { si }\end{array}$ & $\begin{array}{c}\text { Variab } \\
\text { el } \\
\text { \&Sub- } \\
\text { Variab } \\
\text { el }\end{array}$ & $\begin{array}{c}\text { Indikat } \\
\text { or }\end{array}$ & $\begin{array}{c}\text { Ite } \\
\text { ms }\end{array}$ \\
\hline Grup 1 & ada & ada & ada & ada & ada \\
\hline Grup 2 & ada & ada & ada & ada & ada \\
\hline Grup 3 & ada & ada & ada & ada & ada \\
\hline Grup 4 & ada & ada & ada & ada & ada \\
\hline Grup 5 & ada & ada & ada & ada & ada \\
\hline Grup 6 & ada & ada & ada & ada & ada \\
\hline Grup 7 & ada & ada & ada & ada & ada \\
& & & & & \\
\hline
\end{tabular}

Dari tabel 3.2 dapat dilihat bahwa masing-masing kelompok peserta workshop pelatihan pembuatan angket dapat menyelesaikan beberapa kegiatan penting dalam penyusunan angket. Setelah memeriksa kertas kerja tiap kelompok, mereka dapat mengumpulkan 4-6 konsep-konsep teoritis, menuliskan dimensi, menentukan variable $\&$ sub-variabel, menentukan indikator dan membuat items yang berhubungan dengan topik penugasan pembuatan angket yang sudah dibagikan. Dari hasil evaluasi kertas kerja peserta pelatihan, tim pelaksana pengabdian menyimpulkan bahwa kegiatan pelatihan pembuatan angket penelitian kepada mahasiswa pendidikan Bahasa Inggris FKIP 
UNILAK ini memberikan pemahaman dan kemampuan kepada peserta untuk membuat angket penelitian yang baik dan benar sesuai dengan kaedah yang berlaku.

Mahasiswa juga telah diberi penjelasan tentang model pertanyaan angket seperti closed ended, multiple choice questions, open ended questions dan scale items (Wilkinson \& Birmingham, 2003). Adapun jenis angket yang dibuat oleh mahasiswa peserta pelatihan menggunakan scale items dengan model pertanyaan skala Likert. Hal ini dapat dibuktikan dengan penyelesaian tugas pembuatan angket beserta analisis data yang diberikan kepada mahasiswa peserta pelatihan selama kurang lebih 3 minggu.

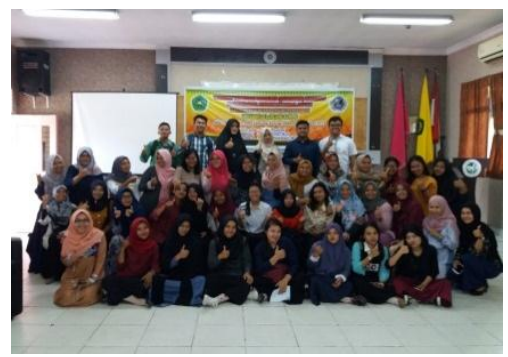

Gambar 4. Pemateri dan Peserta Pelatihan

Secara keseluruhan, kegiatan pelatihan ini dapat berjalan dengan lancar karena adanya kerjasama dan koordinasi yang baik dengan mitra. Kegiatan pelatihan pembuatan instrumen angket penelitian ini telah memberikan dampak positif dimana mahasiswa memahami konsep teoritis tentang angket. Secara teoritis akhirnya mahasiswa peserta dapat menjelaskan aspek-aspek penting dari angket yang sebelumnya mereka tidak dapat menjawab beberapa pertanyaan diagnostik tentang angket. Selanjutnya, secara praktik, mahasiswa peserta pelatihan kini telah memiliki kemampuan dalam membuat angket penelitian sendiri, mengolah dan menganalisis data angket baik secara manual maupun dengan bantuan software.

\section{KESIMPULAN \& SARAN}

Berdasarkan kegiatan pelatihan pembuatan angket penelitian yang sudah dilaksanakan di Fakultas Keguruan dan Ilmu Pendidikan Universitas Lancang Kuning Pekanbaru-Riau selama 3 minggu dapat disimpulkan bahwa:

1. Mitra pengabdian sangat membutuhkan pengetahuan tentang pembuatan instrumen angket untuk digunakan dalam pengumpulan data pada jenis penelitian dengan metode survei dalam rangka memudahkan mereka pada kegiatan penelitian baik untuk memenuhi tugas-tugas penelitian maupun untuk memenuhi penyelesaian tugas akhir mereka.

2. Mitra pengabdian dapat menjelaskan pemahaman mereka tentang angket dan kegunaannya, kesamaan dan perbedaan angket dengan tes, apa yang dimaksud dengan test dan non-test instrumen, hal apa saja yang harus dipersiapkan untuk membuat sebuah angket, apa saja elemen penting pada sebuah angket, berapa pernyataan minimal atau maksimal yang ada pada sebuah angket, apa itu construct validity, perlukah angket divalidasi (expert validation), apa itu "likert scale", apa itu faktor analisis dan apa itu "adopt" dan "adapt" pada sebuah angket, bagaimana mendistribusikan angket, dan bagaimana menskor dan menganalisa angket,

3. Mitra pengabdian mampu membuat angket penelitian dengan mengikuti aturan pembuatan angket secara benar setelah mendapatkan materi pelatihan diikuti dengan sesi simulasi kegiatan pembuatan instrumen angket.

Berdasarkan kesimpulan di atas, perlu diadakan pelatihan pembuatan instrumen penelitian bagi mahasiswa peneliti yang akan maupun sedang menyelesaikan tugas akhir sehingga mereka betul-betul mengumpulkan data penelitian sesuai dengan prosedur pengumpulan data yang benar. Dosen-dosen yang mengampu mata kuliah metode penelitian diharapkan berperan aktif untuk memberikan penjelasan lebih pada metode penelitian survei dan juga teknik pengumpulan data dalam penelitian tersebut yaitu salah satunya adalah instrumen angket. Selanjutnya, kegiatan pelatihan pembuatan instrumen angket penelitian ini perlu ditaja kembali pada sesi berikutnya untuk masuk pada pembahasan analisis faktor yang juga sangat penting dan sarat dengan hitungan data statistik dan interpretasi yang cermat.

\section{DAFTAR PUSTAKA}

Creswell. J.W. 2005. Educational research: Planning, conducting, and evaluating quantitative and qualitative research. Boston: Pearson Education, Inc. 
Gall, M.D., Gall, J.P. \& Borg, W.R. 2003. Educational Research: An Introduction. Allyn and Bacon.

Kasnodiharjo, 1993. Langkah-Langkah Menyusun Kuestioner. Media Litbangkes, Vol.3 (2).

Nazir, M. 2005. Metode Penelitian. Jakarta: Galia Indonesia.

Saleh, 2008. Enam Tradisi Besar Penelitian pendidikan Bahasa. Semarang: UNNES Press.

Wilkinson, D. \& Birmingham, P. 2003. Using Research Instruments: A Guide for Researchers. London: Routledge Falmer. 